\title{
CONCERN FOR ECONOMIC RESULTS AND CORPORATE SOCIAL RESPONSIBILITY - A COMPARATIVE STUDY OF LITHUANIA AND SLOVENIA
}

\author{
Vojko Potocan $^{1}$, Zlatko Nedelko ${ }^{2}$, \\ Valentina Peleckiené ${ }^{3}$, Kęstutis Peleckis ${ }^{4}$, \\ Giedrè Lapinskien $\dot{e}^{5}$, Kęstutis Peleckis ${ }^{6}$
}

\author{
${ }_{1,2}^{2}$ Department of Management and Organization, Faculty of Economics and Business, \\ University of Maribor, Razlagova 14, 2000 Maribor, Slovenia \\ ${ }^{3}$ Department of Management, Faculty of Business Management, \\ Vilnius Gediminas Technical University, Saulètekio al. 11, LT-10223, Vilnius, Lithuania \\ ${ }^{4,5}$ Department of Business Technologies and Entrepreneurship, Faculty of Business Management, \\ Vilnius Gediminas Technical University, Saulètekio al. 11, LT-10223, Vilnius, Lithuania \\ ${ }^{6}$ Department of Economics Engineering, Faculty of Business Management, \\ Vilnius Gediminas Technical University, Saulètekio al. 11, LT-10223, Vilnius, Lithuania \\ E-mails: ${ }^{1}$ vojko.potocan@um.si (correspondingauthor); ${ }^{2}$ zlatko.nedelko@um.si; \\ ${ }^{3}$ valentina.peleckiene@vgtu.lt; ${ }^{4}$ kestutis.peleckis@vgtu.lt; ${ }^{5}$ giedre.lapinskiene@vgtu.lt; \\ ${ }^{6}$ k.peleckis@vgtu.lt
}

\begin{abstract}
The purpose of this draft paper is to empirically examine the role of concern for economic results for shaping corporate social responsibility in Lithuania and Slovenia. Results are based on 80 answers of students from Lithuania and 101 answers of students from Slovenia. Results reveal that Slovenian students on average show significantly higher concern for corporate social responsibility, as well as for economic results, than their Lithuanian counterparts. Similarly in both countries, students perceive organizations concern to pay the full financial cost of using energy and natural resources as most significant factor shaping corporate social responsibility. Findings are important for practitioners and for academia, which get insight into the perception of corporate social responsibility of their future employees.
\end{abstract}

Keywords: concern for economic results, corporate social responsibility, Slovenia, Lithuania, millennials.

JEL Classification: M 14.

\section{Introduction}

The literature offers abundant evidences and researches about corporate social responsibility (Carroll, 1999; Glavas \& Kelley, 2014; McWilliams \& Siegel, 2001; Nedelko \& Potocan, 2014). The literature in the domain of corporate social responsibility offers plethora of evidences about its development as a concept (Carroll, 1999), about current state of corporate social responsibility in organizations (Foote, Gaffney, \& Evans, 2010; Nedelko \& Potocan, 2014; Wang, Tong, Takeuchi, \& George, 2016), the impact of personal values on shaping corporate social responsibility (Hemingway, 2005; Potocan \& Nedelko, 2015; Wynder \& Dunbar, 2016), to mention some of the researches.

Looking at the existing literature through the lenses of three key pillars of corporate social re- sponsibility - namely economic, natural and social pillar (Elkington, 2004), dominant are studies focusing on natural aspect of corporate social responsibility. In the forefront is natural aspect of corporate social responsibility, which has been receiving a lot of attention in the last two-three decades. In frame of natural aspect studies are addressing pro-environmental behavior (Nordlund \& Garvill, 2002; Oreg \& Katz-Gerro, 2006), environmental responsiveness (Papagiannakis \& Lioukas, 2012; Potocan, Nedelko, Peleckienè, \& Peleckis, 2016), environmental concern (Alibeli \& Johnson, 2009; Schultz, 2001), environmental accountability (Bhattacharyya, 2016), environmental values (Dietz, Fitzgerald, \& Shwom, 2005; Karp, 1996; Kemmelmeier, Krol, \& Kim, 2002), to outline those among most commonly addressed. 
Social aspect of corporate social responsibility is also gaining on its importance recently. But unlike to the natural aspect, which is often solely considered, societal aspect is usually considered as part of the discussion about corporate social responsibility (Nedelko \& Potocan, 2014).

Among three key pillars of corporate social responsibility, considerably less attention has been given to the role of economic aspect in frame of its role in shaping corporate social responsibility. There are some studies, considering economic aspect in frame of social responsibility, but they are rare. For instance, Potocan et al. (2016) considered economic concern as predictor of enterprise environmental responsiveness.

Although there are numerous papers, that have examined relationships between corporate social responsibility and organizational financial performance (Agle, Mitchell, \& Sonnenfeld, 1999; Aupperle, Carroll, \& Hatfield, 1985; Bhardwaj, Chatterjee, Demir, \& Turut, 2018; McGuire, Sundgren, \& Schneeweis, 1988; Price $\&$ Sun, 2017), but their aim was to research justification of corporate social responsibility, though the lenses of financials. Thus, all these studies consider economic aspect of corporate social responsibility, through the lenses of "justification of corporate social responsibility" without taking into account behavioral aspect, which put in the centre of attention, how economic aspect of corporate social responsibility is shaping corporate social responsibility.

In terms of the participants in the empirical surveys dealing with corporate social responsibility, majority of the studies are focusing on examination of current state of corporate social responsibility, as perceived by their employees (Aupperle et al., 1985; Furrer et al., 2010), while there are also several evidences about examination of corporate social responsibility based on the students answers (Bhattacharyya, 2016; Eagle, Low, Case, \& Vandommele, 2015).

Due to the lack of empirical studies addressing students' perception of corporate social responsibility in current business circumstances, organizations don't have a comprehensive insight into the student's perception of corporate social responsibility. This knowledge is important since students represent future employees in organizations. What is more, there are some notable suggestions, that current generations of students, often called "millennials" are different from other generations currently at workplace (Ng, Schweitzer, \& Lyons, 2010), regarding advancement, benefits, etc. Besides those outlined, social responsibility issues does not play a significant role in millennials life. Theses possible differences may have implications for their perception of corporate social responsibility in the future and would be beneficial to examine their attitudes toward corporate social responsibility as well.

All above outlined cognitions, about lack of studies regarding economic aspect in frame of corporate social responsibility, lack of empirical justification of the association between economic concern and corporate social responsibility, and lack of knowledge about perception of the new generations of employees regarding corporate social responsibly call for deeper examination how students perceive the economic concern and corporate social responsibility in nowadays society.

The aim of this study is to empirically examine the association between economic aspect of corporate social responsibility and corporate social responsibility, which represent the missing link in the existing literature, based on the samples of new generations of future employees. Accordingly, the study is conducted on the samples of business students. For the purpose of this study, we used data from Slovenia and Lithuania, as representative of countries that entered EU in the same wave having some cultural as well as developmental differences, in terms of their paths toward free-market economy (Kornai, 1992; Potočan \& Mulej, 2007).

In line with the main purpose, the structure of the paper is as follows. First we outline theoretical foundations about corporate social responsibility and the economic aspect of corporate social responsibility, where we also develop research questions. Second part is dedicated to the methodology of research, while third part is presenting the results of field study. Final part is dedicated to the discussion of the results, implications, limitations and future research directions.

\section{Theoretical background}

In next paragraphs below we first address the theoretical foundations for understanding the phenomena of corporate social responsibility. In the rest of this chapter we are focusing on economic concern and adjacent issues in frame of corporate social responsibility. 


\subsection{Corporate social responsibility}

In current highly competitive global economy organizations needs to be highly innovative (Alas, Elenurm, \& Tafel-Viia, 2010; Collins \& Porras, 2002; Skarzynski \& Gibson, 2008). Besides that, there has been for a long time also the need to satisfy various stakeholders interests, ranging from shareholders, consumers, government, local society, etc, (Agle, Nagarajan, Sonnenfeld, \& Srinivasan, 2006; Potocan \& Nedelko, 2015; Schermerhorn, 2008; Valackiene \& Miceviciene, 2015; Wang et al., 2016).

S. C. Certo and S. T. Certo (2009, p. 79) defined corporate social responsibility as "the managerial obligation to take actions that protects and improves both, the welfare of society as whole and the interests of organization". Schermerhorn (2008, p. 44) defines corporate social responsibility as "the obligation of organization to serve its own interests and those of society".

According to the three dimensions of corporate social responsibility, incorporation of corporate social responsibility principles in organizations goals emphasize the need to tradeoff between pursuing economical, environmental, and societal goals of organizations (Agle et al., 1999; Godos-Diez, Fernandez-Gago, \& Martinez-Campillo, 2011; Vitell \& Hidalgo, 2006).

Organizations involvement in corporate social responsibility activities have become an important part of organizational activities (Agle et al., 2006; Beckerman, 1994; Dima, Vasilache, Ghinea, \& Agoston, 2013; Mitchell, Agle, \& Wood, 1997) and necessary in nowadays business environment. Major arguments for organizations to perform corporate social responsibility activities are related to (S. C. Certo \& S. T. Certo, 2009): (1) the fact that organizations have significant impact on such critical issues as environmental pollution, influencing quality of people in neighborhood of organizational premises, (2) the fact that organizations are open system, thus they should listen to what must be done to sustain or improve social welfare, (3) severe depletion of natural resources, increased social problems, and greed for profits, in last decades, and (4) increased role and importance of national legislation, European Union legislation, activist groups, non-governmental organizations, customers, etc., for sustainable development.

Besides term corporate social responsibility, its main idea can be found under different names/appearances forms, like corporate sustainability (Baumgartner \& Ebner, 2010) or sustainability (Beckerman, 1994; Blackburn, 2007). Sustainability is a holistic concept, but the vision that none of the development goals of economic growth, social wellbeing and a wise use of natural resources, can be reached without considering and effecting the other two, got widely accepted (Landrum \& Edwards, 2009). John Elkington (2004) developed this notion into the 'triple bottom line' or 'Triple-P (People, Planet, Profit)' concept.

Prior studies in area of corporate social responsibility (Axelrod \& Lehman, 1993; Kemmelmeier et al., 2002; Schultz, 2001; Stern, 2000) showed their focus on the environmental dimension of corporate social responsibility and therefore fail to acknowledge the holistic principle of the "three underlying dimensions of corporate social responsibility" (Clayton \& Radcliffe, 1996; Ketola, 2008). Several authors (Clayton \& Radcliffe, 1996; Elkington, 2004; Potocan, Mulej, \& Nedelko, 2013) argued, that the socio-cultural, environmental and economic realms are interdependent and the aim of a sustainably managed business should be the optimization of all three.

Taking into the consideration three underlying pillars of corporate social responsibility, a significant less attention is given to the economic aspect, in comparison to the other two aspects, especially the natural aspect of corporate social responsibility. Thus, next we are focusing on the reviewing the literature in the area of economic aspect of corporate social responsibility.

\subsection{Economic concern and corporate social responsibility}

Concern for economic results can be most generally defined as worrying foremost about the economic results of enterprises' workings and behavior (Baumol, Litan, \& Schramm, 2007; Buchanan \& Huczynski, 2010).

Despite numerous papers addressing economic aspect of corporate social responsibility, these papers are mainly addressing the association between corporate social responsibility and organizational financial performance (Agle et al., 1999; Aupperle et al., 1985; Bhardwaj et al., 2018; McGuire et al., 1988; Price \& Sun, 2017), in terms of justification of corporate social responsibility and its impact on organizational finances.

To sum up, there are several papers empirically examining relationship between corporate 
social responsibility and firm performance, where some (Bhardwaj et al., 2018): (1) find positive relations between corporate social responsibility and organizational performance; (2) find negative relationship; and (3) report in-significant relationship.

Although availability of plethora of studies, these studies do not reveal how economic aspect of corporate social responsibility is shaping corporate social responsibility, as some other studies report about the impact of natural and social aspect on shaping corporate social responsibility (Nedelko \& Potocan, 2014; Potocan et al., 2016).

Looking from the perspective how individuals' perception of concern for economic results shape corporate social responsibility, the available literature does not provide a sufficient answer.

In our seminal research we are going to examine how individual's concern for economic result, through the individuals' perception of concern for economic results, is shaping corporate social responsibility.

In line with the aims of this study, there are no well established measures for capturing individual preferences about economic concern. This is due to the focus on "justification of corporate social responsibility", which is usually measured using well-established financial measures and on the organizational level. For instance, a survey focusing on justification of corporate social responsibility in organizations, is based on accountingbased measures (e.g. return on assets, return on equity) (Agle et al., 1999).

In this research we examined economic aspect of corporate social responsibility, as perceived by the students. This means that we asked participants about their attitudes regarding concern for economic results, not focusing on quantitative expression of economics results. In search for dimensions or constructs aimed to measure "profit or economic orientation" (e.g. how much is important achieving economic profits, we emphasize a research about leadership orientation, where the focus was on performance goal orientation (Pastor \& Mayo, 2008).

Our research will be done on the samples of students from Slovenia and Lithuania, where we are interested to examine current state of corporate social responsibility, preferences about economic concern as well as the associations between corporate social responsibility and economic concern for students having different backgrounds.

For instance, Slovenia and Lithuania, are representative of countries that entered EU in the same wave, while having some cultural as well as developmental differences, in terms of their paths toward free-market economy (Kornai, 1992; Potočan \& Mulej, 2007). Slovenia experienced a so called self-management system in frame of socialism, while Lithuania have experiences typical socialistic regime (Bakacsi, Sandor, Karacsonyi, \& Imrek, 2002; Bučar \& Stare, 2002; Marangos, 2005; Mulej \& Kajzer, 1998; Schumpeter, 1992).

Although some outlined differences in terms of cultural, economic and country's developmental background, both samples share some common characteristics - students in both countries can be considered as "millennials, sharing several common characteristics. Millennials are future employees in organizations and their characteristics are rather different from those generations that precede them in organizations, According to the $\mathrm{Ng}$ et al. (2010) research the most prominent characteristic of millennials is their desire for fast career advancement, large pay increases and often giving advantage for work and leisure over family. Besides this, social responsibility issues do not play a significant role in millennials life. These attributes, especially the last one, may have implications for their perception of corporate social responsibility in the future and would be beneficial to examine their attitudes toward corporate social responsibility as well.

In line with above findings regarding the economic aspect of corporate social responsibility and corporate social responsibility, we postulate following research questions.

Research question 1 - are there any differences regarding concern for economic results between Lithuania and Slovenia?

Research question 2 - are there any differences regarding perception of corporate social responsibility between Lithuania and Slovenia?

Research question 3 - is there any impact of concern for economic results on corporate social responsibility, in Lithuania and Slovenia?

\section{Methodology}

\subsection{Instrument}

For this research we modified a survey which was originally used for examining various aspects of ethics in organizations (Ralston et al., 2011). In the first part we included a list of values from Schwartz's value survey (Schwartz, 1992; Schwartz et al., 2012); in the second part 25 items aimed to measure different aspects of enterprises' social responsibility and related social responsible behavior from international research groups were adopted (Furrer et al., 2010; Ralston et al., 2011). 
In the last part we asked participants about typical demographic data in business research.

\subsection{Sample and procedure}

The sample included 80 respondents from Lithuania and 101 respondents from Slovenia. Survey was conducted among students having major in economics and business. In Lithuania the survey was done at Vilnius Gediminas technical university and in Slovenia, the survey was done at University of Maribor, Faculty of economics in business.

In both countries, the survey was conducted in the academic year 2017/2018 and included students from all years, fields and levels of study. The surveying was done among classes and all students participated voluntarily.

In terms of sample characteristics, we can outline following. The average age of students in Lithuanian sample 20.74 years and in Slovenian sample 21.64 years. In terms of gender, in Lithuanian sample there are 31.3 percent of males and 68.8 percent of females. In Slovenia the ratio is very similar, having 26.7 percent of males and 73.3 percent of females.

\subsection{Measures}

A 9-point scale, ranging from 1 (strongly disagree) to 9 (strongly agree), was used, for measuring the items, which comprises two latent variables Based on factorial analysis of the 25 items from third part of the questionnaire aiming on measuring various aspects of corporate social responsibility, we focused on those related to the economic issues and socially responsible behavior. Based on the results of factorial analysis, using varimax rotation, we created two variables to capture economic aspect of social responsibility and one variable aimed to describe corporate socially responsible behavior.

Concern for economic results - is accurately and reliably represented with five items regarding economic issues in organizations, namely: (1) worry first and foremost about maximizing profits (EC 1 - profit maximization); (2) pay the full financial cost of using energy and natural resources (EC 2 - full cost payment); (3) bring down their labor costs to a strict minimum (EC 3 minimizing labor costs); (4) refrain from bending the law even if doing so could improve performance (EC 4 -respecting the law); and (5) always be concerned first about economic performance (EC 5 - profit is highest priority). Cronbach's $\alpha$ for this scale was 0.680 .
Corporate social responsibility - is accurately and reliably represented with six items regarding basic characteristics of corporate social responsibility, namely: (1) preventing environmental degradation caused by the pollution and depletion of natural resources (CSR - 1); (2) devoting resources to environmental protection even when economic profits are threatened (CSR -2$)$; (3) plan for organizational long term success (CSR - 3); (4) voluntarily exceed government environmental regulations (CSR - 4); (5) play a role in our society that goes beyond the mere generation of profits (CSR - 5); and (6) only proceed with activities for which environmental risks can be fully evaluated and controlled (CSR - 6). Cronbach's $\alpha$ for this scale was 0.816 .

\subsection{Research design and analysis}

Our research has three stages. In the first stage we examined zero-ordered correlations among variables of interest in our study. Next, we used independent samples t-test to examine whether significant differences exists between Lithuanian and Slovenian students regarding their perception of concern for economic results and corporate social responsibility. In third step we used hierarchical regression analysis to determine the impact of economic concern on corporate social responsibility, while also controlling for some demographic variables. In the model 1 we entered control variables - age, gender and education. In model 2 we entered five items representing concern for economic results.

\section{Results}

Table 1 shows mean values, standard deviations and zero-ordered correlations among the study variables.

Looking from the perspective of our study, we can emphasize following important findings. First, items aimed to measure economic concern of individuals are all significantly associated with perceived corporate social responsibility and are good indicators of significant associations. Second, country has significant association between items regarding concern for economic results, as well as with corporate social responsibility.

Accordingly, we ran independent samples t-test (see Table 2), which reveals us mean values and results about possible differences between Lithuania and Slovenia. 
Table 1. Mean values, standard deviations and correlations among the study variables ${ }^{\mathrm{a}}$

\begin{tabular}{|c|c|c|c|c|c|c|c|c|c|c|c|}
\hline Variable & M & SD & 1 & 2 & 3 & 4 & 5 & 6 & 7 & 8 & 9 \\
\hline Age & 21.24 & 1.38 & 1 & & & & & & & & \\
\hline Gender & 1.71 & .45 & $-.21 * *$ & 1 & & & & & & & \\
\hline Education & 3.57 & .54 & .02 & -.06 & 1 & & & & & & \\
\hline Country & .81 & .19 & $.33 * * *$ & .05 & $-.77 * * *$ & 1 & & & & & \\
\hline $\begin{array}{l}\text { EC } 1 \text { - profit } \\
\text { maximization }\end{array}$ & 5.83 & 2.09 & .10 & .06 & $-.43 * * *$ & $.53 * * *$ & 1 & & & & \\
\hline $\begin{array}{l}\text { EC } 2 \text { - full } \\
\text { cost payment }\end{array}$ & 5.55 & 2.47 & $.18^{*}$ & .06 & $-.47 * * *$ & $.60 * * *$ & $.29 * * *$ & 1 & & & \\
\hline $\begin{array}{l}\text { EC } 3 \text { - mini- } \\
\text { mizing labor } \\
\text { costs }\end{array}$ & 5.14 & 2.51 & -.00 & -.03 & -.11 & .12 & $.22 * *$ & $.24 * *$ & 1 & & \\
\hline $\begin{array}{l}\text { EC } 4-\text { re- } \\
\text { specting the } \\
\text { law }\end{array}$ & 5.81 & 2.40 & $.19 *$ & .11 & $-.35 * * *$ & $.49 * * *$ & $.29 * * *$ & $.59 * * *$ & $.22 * *$ & 1 & \\
\hline $\begin{array}{l}\text { EC } 5 \text { - profit } \\
\text { is highest pri- } \\
\text { ority }\end{array}$ & 4.94 & 1.98 & .08 & -.09 & $-.33 * * *$ & $.33 * * *$ & $.48 * * *$ & $.19 * *$ & $.29 * * *$ & $.21 * *$ & 1 \\
\hline $\begin{array}{l}\text { Corporate so- } \\
\text { cial responsi- } \\
\text { bility }\end{array}$ & 5.66 & 1.72 & $.25^{* *}$ & .01 & $-.65 * * *$ & $.83^{* * *}$ & $.36^{* * *}$ & $.67 * * *$ & $.20 * *$ & $.50 * * *$ & $.29 * * *$ \\
\hline
\end{tabular}

${ }^{a} \mathrm{~N}=181$

$* p<.05$

$* * p<.01$

$* * * p<.001$

Table 2. Concern for economic results and corporate social responsibility in Lithuania and Slovenia ${ }^{\mathrm{a}}$

\begin{tabular}{|l|c|c|c|c|c|}
\hline \multirow{2}{*}{ Variables } & \multicolumn{2}{|c|}{ Lithuania } & \multicolumn{2}{c|}{ Slovenia } & \multirow{2}{*}{ t-test } \\
\cline { 2 - 5 } & Mean & SD & Mean & SD & $-8.26^{* * *}$ \\
\hline EC 1 - profit maximization & 4.60 & 1.80 & 6.80 & 1.76 & 1.93 \\
\hline EC 2 - full cost payment & 3.87 & 2.03 & 6.87 & 2.57 & $-10.14^{* * *}$ \\
\hline $\begin{array}{l}\text { EC 3 - minimizing labor } \\
\text { costs }\end{array}$ & 4.80 & 2.40 & 5.40 & 2.07 & $-7.52^{* * *}$ \\
\hline EC 4 - respecting the law & 4.49 & 2.13 & 6.85 & 2.12 & $-4.86^{* * *}$ \\
\hline $\begin{array}{l}\text { EC 5 - profit is highest } \\
\text { priority }\end{array}$ & 4.21 & 1.51 & 5.52 & .92 & $-19.78^{* * *}$ \\
\hline $\begin{array}{l}\text { Corporate social responsi- } \\
\text { bility }\end{array}$ & 4.06 & .99 & 6.90 & & \\
\hline
\end{tabular}

$* p<.05$

$* * p<.01$

$* * * p<.001$

In terms of postulated research questions, above results, provide positive answers for research question 1 - which is asking if there are any differences regarding concern for economic results between Lithuania and Slovenia? i.e. for four items regarding concern for economic results, dif- ferences between Lithuania and Slovenia are significant. Regarding research question 2 - which is asking if there are any differences regarding perception of corporate social responsibility between Lithuania and Slovenia? we can provide again positive answer. 
Finally, we provide results from regression analysis, where we tested the impact of items representing economic concern on corporate social responsibility separately for Lithuania and Slovenia (see Table 3). In the first step of the analysis we entered control variables (model 1), while in the second step we entered five items representing concern for economic results (model 2).

Table 3. Hierarchical regression analysis of economic concern on corporate social responsibility for Lithuania and Slovenia

\begin{tabular}{|c|c|c|c|c|}
\hline \multirow[b]{2}{*}{ Variables } & \multicolumn{2}{|c|}{ Lithuania } & \multicolumn{2}{|c|}{ Slovenia } \\
\hline & $\begin{array}{c}\text { Model } \\
1\end{array}$ & $\begin{array}{c}\text { Model } \\
2\end{array}$ & $\begin{array}{c}\text { Model } \\
1\end{array}$ & $\begin{array}{c}\text { Model } \\
2\end{array}$ \\
\hline $\begin{array}{l}\text { Block 1: } \\
\text { Controls }\end{array}$ & & & & \\
\hline Age & $-.28 *$ & $-.33 * *$ & .06 & .10 \\
\hline Gender & -.13 & -.13 & .06 & .04 \\
\hline Education & -.20 & -.16 & .03 & -.05 \\
\hline $\begin{array}{l}\text { Block } \\
2: \text { Concern } \\
\text { for eco- } \\
\text { nomic } \\
\text { results }\end{array}$ & & & & \\
\hline $\begin{array}{l}\text { EC 1 - } \\
\text { profit max- } \\
\text { imization }\end{array}$ & & -.12 & & $-.25 *$ \\
\hline $\begin{array}{l}\text { EC } 2 \text { - full } \\
\text { cost pay- } \\
\text { ment }\end{array}$ & & $.31 * *$ & & $.36^{* *}$ \\
\hline $\begin{array}{l}\text { EC } 3- \\
\text { minimizing } \\
\text { labor costs }\end{array}$ & & $.26 * *$ & & .05 \\
\hline $\begin{array}{l}\text { EC } 4-\text { re- } \\
\text { specting } \\
\text { the law }\end{array}$ & & .04 & & -.04 \\
\hline $\begin{array}{l}\text { EC 5 - } \\
\text { profit is } \\
\text { highest } \\
\text { priority }\end{array}$ & & .20 & & -.02 \\
\hline$n$ & 76 & 76 & 100 & 100 \\
\hline $\mathrm{R}^{2}$ & .13 & .41 & .01 & .21 \\
\hline Model F & $3.69 *$ & $5.83 * * *$ & .23 & $3.00 * *$ \\
\hline
\end{tabular}

Regarding research question 3 - which is asking if there are any impact of concern for economic results on corporate social responsibility, in Lithuania and Slovenia? it is evident that in each country 2 items representing concern for economic results have significant impact on shaping corporate social responsibility.

\section{Implications}

The findings from this research are especially useful to provide an insight into the actual perception of corporate social responsibility and attitudes toward economic concern of future generations of employees. Based on these findings organizations can shape their policies regarding future corporate social responsibility. For instance, knowing actual of state future employees, can help organizations to provide actions in order to ensure better fit between their policies and principles regarding corporate social responsibility and newcomers in the organizations, since care for social responsibility is not among top priority of new generation $(\mathrm{Ng}$ et al., 2010). In frame of achieving better alignment between organizations corporate social responsibility and newcomers' attitudes toward social responsibility, in-service trainings and workshops should be used.

Another implication could also be for the academia, which can adopt their curricula in the way that will better support orientation toward higher level of corporate social responsibility - i.e. to increase student's awareness about corporate social responsibility. Thus, these "deficitary areas", should be incorporated into the curricula of the subjects in order to enhance those characteristics which support increase of corporate social responsibility, while diminish the effect of those which have negative impact on corporate social responsibility.

For instance, in both countries, the most emphasis should be given to the "paying of full financial cost of using energy and natural resources", as well as to the attitudes about profit maximization in Lithuania and minimization of labor cost in Slovenia.

\section{Limitations}

This paper has some limitations. First, the focus is on the relationship between economic concern and corporate social responsibly, while not considering the role of natural and social aspects on corporate social responsibility - which are two out of three building blocks of corporate social responsibility (Elkington, 2004).

Second, in frame of examining the impact of economic concern on corporate social responsibility, the focus is on examining the associations between single items representing the concern for economic results on corporate social responsibility, which is considered as latent variable, comprising of several items. 
Third, the self-assessment scale is used, where students by themselves assessed their perception of economic results as well as their perception about corporate social responsibility. This may have some implications for the obtained results (Schwartz, 1999).

Finally, the minor limitation can be related to the size of the sample and the non-random sampling, since students from one university in both countries were included in the survey. This may have implications for the results.

\section{Future research}

In terms of possible future research directions, findings in this paper outline several possible future research directions. First, to examine the impact of important moderator variables regarding the relationship between economic concern and the perception of corporate social responsibility. According to the three underlying pillars of the corporate social responsibility - namely natural, social and economic, concern for natural and concern for social environment are possible moderator variables since there are several empirical studies revealing the impact of natural and social concern on social responsibility (Potocan et al., 2016)

Next, it would be beneficial to examine the impact of personal values on perception of corporate social responsibility (Schultz \& Zelezny, 1999), since personal values are recognized as important factor, that determined manager's attitudes toward environmental concern, economic concern and corporate environmental responsiveness (Potocan et al., 2016).

For instance, both age and education, which are usually perfectly correlated, showed in aggregated sample of Lithuania and Slovenia significant influence on corporate social responsibility. For that purpose it would be beneficial to examine the role of the level of the education, like first year in comparison to the senior year of study, and determine if those two groups may differ in their perception of corporate social responsibility.

Finally, a comparison with employees' samples would be very beneficial, since surveyed students are future employees. This comparison will reveal what are gaps between perception of corporate social responsibility by current employees and future employees, currently considered as students, due to the generational differences $(\mathrm{Ng}$ et al., 2010).

\section{Conclusions}

This paper examined the role of concern for economic results for shaping corporate social responsibility perception by Lithuanian and Slovenian sample. Results show that Slovenian students highly appreciate corporate social responsibility than Lithuanian students, while in both countries issues regarding payment of full financial cost of using energy and natural resources are most significant driver for shaping perception about corporate social responsibility. Differences between both samples in the study can have its roots in so$\mathrm{cial} /$ political/economic development, cultural differences, field of study, year of study, etc. Our results reveal that examination of perception of corporate social responsibility of future generations of employees - in our case samples of "millenials" is very promising and call for future examination in this area. Millenials have some distinguishing characteristics, in comparison to other groups, like adults. This requires a deeper examination in this area will provide use many useful insight into the future of corporate social responsibility in organizations.

\section{References}

Agle, B. R., Mitchell, R. K., \& Sonnenfeld, J. A. (1999). Who Matters to Ceos? An investigation of stakeholder attributes and salience, Corpo-rate performance, and Ceo values. Academy of Management Journal, 42(5), 507-525.

Agle, B. R., Nagarajan, N. J., Sonnenfeld, J. A., \& Srinivasan, D. (2006). Does Ceo Charisma Matter? An empirical analysis of the relationships among organizational performance, environmental uncertainty, and top management team Perceptions of Ceo Charisma. Academy of Management Journal, 49(1), 161-174. https://doi.org/10.5465/amj.2006.20785800

Alas, R., Elenurm, T., \& Tafel-Viia, K. (2010). Who is driving change? Corporate governance and organizational change in Estonia. Journal of Baltic Studies, 41(1), 2343. https://doi.org/10.1080/01629770903525308

Alibeli, M., \& Johnson, C. (2009). Environmental concern: A cross national analysis, Journal of International and Cross-cultural Studies, 3(1), 1-10.

Aupperle, K E., Carroll, A. B., \& Hatfield, J. D. (1985). An empirical examination of the relationship between corporate social responsibility and profitability. The Academy of Management Journal, 28(2), 446-463.

Axelrod, L. J., \& Lehman, D. R. (1993). Responding to environmental concerns - what factors guide individual action. Journal of Environmental Psychology, 13(2), 149159. https://doi.org/10.1016/S0272-4944(05)80147-1

Bakacsi, G., Sandor, T., Karacsonyi, A., \& Imrek, V. (2002). Eastern European cluster: Tradition and transition. Journal of World Business, 37(1), 69-80. https://doi.org/10.1016/S1090-9516(01)00075-X

Baumgartner, R. J., \& Ebner, D. (2010). Corporate sustainability strategies: Sustainability profiles and maturity levels. Sustainable Development, 18(2), 76-89. https://doi.org/10.1002/sd.447 
Baumol, W., Litan, R. E., \& Schramm, C., J. (2007). Good capitalism, bad capitalism and the economics of growth and prosperity. London, UK: Yale University Press. 336 p. https://doi.org/10.2139/ssrn. 985843

Beckerman, W. (1994). Sustainable development - is it a useful concept. Environmental Values, 3(3), 191-209. https://doi.org/10.3197/096327194776679700

Bhardwaj, Pradeep., Chatterjee, Prabirendra., Demir, Kivilcim. Dogerlioglu., Turut, Ozge. (2018). When and how is corporate social responsibility profitable?. Journal of Business Research, 84: 206-219. https://doi.org/10.1016/j.jbusres.2017.11.026

Bhattacharyya, Asit. (2016). Personal values and attitudes towards societal and environmental accountability: A study of MBA students. Environmental Education Research, 22(4), 590-610. https://doi.org/10.1080/13504622.2014.966658

Blackburn, W. (2007). The sustainability handbook: The complete management guide to achieving social, economic and environmental responsibility. London, United Kingdom: Earthscan Publications.

Bučar, M., \& Stare, M. (2002). Macroeconomic policy Vs. Innovation policy in the transition countries EU enlargement in a changing world (Izdaja $\mathrm{Na} \mathrm{Cd}-\mathrm{Romu}$ ). Ljubljana: Inštitut za ekonomska raziskovanja.

Buchanan, D. A., \& Huczynski, A. A. (2010). Organizational behaviour. Harlow Essex: FT Prentice Hall.

Carroll, A. B. (1999). Corporate social responsibility: Evolution of a definitional construct. Business \& Society, 38(3), 268-295.

https://doi.org/10.1177/000765039903800303

Certo, S. C., \& Certo, S. T. (2009). Modern management: Concepts and skills. New Jersey, Upper Saddle Riverm, NJ: Pearson Education.

Clayton, T., \& Radcliffe, N. (1996). Sustainability: A systems approach. London, United Kingdom: Routledge.

Collins, J., \& Porras, J. I. (2002). Built to last: Successful habits of visionary companies. New York, NY: Harper Collins Publishers.

Dietz, T., Fitzgerald, A., \& Shwom, R. (2005). Environmental Values. Annual Review of Environment and Resources, 30(1), 335-372.

https://doi.org/ 10.1146/annurev.energy.30.050504.144444

Dima, A. M., Vasilache, S., Ghinea, V., \& Agoston, S. (2013). A model of academic social responsibility. Transylvanian Review of Administrative Sciences, (38E), 23-43.

Eagle, L., Low, D., Case, P., \& Vandommele, L. (2015). Attitudes of undergraduate business students toward sustainability issues. International Journal of Sustainability in Higher Education, 16(5), 650-668. https://doi.org/10.1108/IJSHE-04-2014-0054

Elkington, J. (2004). Enter the triple bottom line. In A. Henriques \& J. Richardson (Eds.), The triple bottom line: Does it all add up (pp. 1-16). London, United Kingdom: Earthscan.

Foote, J., Gaffney, N., \& Evans, J. R. (2010). Corporate social responsibility: Implications for performance excellence. Total Quality Management \& Business Excellence, 21(8), 799-812. https://doi.org/10.1080/14783363.2010.487660

Furrer, O., Egri, C. P., Ralston, D. A., Danis, W., Reynaud, E., Naoumova, I., \& Furrer-Perrinjaquet, A. (2010). Attitudes toward corporate responsibilities in Western Europe and in Central and East Europe. Management International Review, 50(3), 379-398. https://doi.org/10.1007/s11575-010-0034-3
Glavas, A., \& Kelley, K. (2014). The effects of perceived corporate social responsibility on employee attitudes. Business Ethics Quarterly, 24(2), 165-202. https://doi.org/10.5840/beq20143206

Godos-Diez, J. L., Fernandez-Gago, R., \& MartinezCampillo, A. (2011). How important are Ceos to Csr practices? An analysis of the mediating effect of the perceived role of ethics and social responsibility. Journal of Business Ethics, 98(4), 531-548.

https://doi.org/10.1007/s10551-010-0609-8

Hemingway, C. A. (2005). Personal values as a catalyst for corporate social entrepreneurship. Journal of Business Ethics, 60(3), 233-249. https://doi.org/10.1007/s10551-005-0132-5

Karp, D. G. (1996). Values and their effect on pro-environmental behavior. Environment and Behavior, 28(1), 111-133. https://doi.org/10.1177/0013916596281006

Kemmelmeier, M., Krol, G., \& Kim, Y. H. (2002). Values, economics, and proenvironmental attitudes in 22 societies. Cross-Cultural Research, 36(3), 256-285. https://doi.org/10.1177/10697102036003004

Ketola, T. (2008). A holistic corporate responsibility model: Integrating values, discourses and actions. Journal of Business Ethics, 80(3), 419-435. https://doi.org/10.1007/s10551-007-9428-y

Kornai, J. (1992). The socialist system: The political economy of communism. New Jersey: Princeton University Press. https://doi.org/10.1093/0198287763.001.0001

Landrum, N. E., \& Edwards, S. (2009). Sustainable business: An executive's primer. New York, NY: Business Expert Press. https://doi.org/10.4128/9781606490495

Marangos, J. (2005). Alternative paths to the transition process. International Journal of Social Economics, 32(4), 307-324. https://doi.org/10.1108/03068290510587033

McGuire, J. B., Sundgren, A., \& Schneeweis, Th. (1988). Corporate social responsibility and firm financial performance. The Academy of Management Journal, 31(4), 854-872.

McWilliams, A., \& Siegel, D. (2001). Corporate social responsibility: A theory of the firm perspective. The Academy of Management Review, 26(1), 117-127. https://doi.org/10.5465/amr.2001.4011987

Mitchell, R. K., Agle, B. R., \& Wood, D. J. (1997). Toward a theory of stakeholder identification and salience: Defining the principle of who and what really counts. Academy of Management Review, 22(4), 853-886. https://doi.org/10.5465/amr.1997.9711022105

Mulej, M., \& Kajzer, Š. (1998). Self-transformation and transition from a preindustrial to contemporary economy and society. In R. G. Dyck, \& M. Mulej (Eds.), Selftransformation of the forgotten four-fifths (pp. 325331). Dubuque, Iowa: Kendall/Hunt Publishing Company.

Nedelko, Z., \& Potocan, V. (2014). Perception of corporate social responsibility by the employees: Evidence from Slovenia empowering organizations through corporate social responsibility (pp. 51-72).

Ng, E. S. W., Schweitzer, L., \& Lyons, S. T. (2010). New generation, great expectations: A field study of the millennial generation. Journal of Business and Psychology, 25(2), 281-292. https://doi.org/10.1007/s10869-010-9159-4 
Nordlund, A. M., \& Garvill, J. (2002). Value structures behind proenvironmental behavior. Environment and Behavior, 34(6), 740-756. https://doi.org/10.1177/001391602237244

Oreg, S., \& Katz-Gerro, T. (2006). Predicting proenvironmental behavior cross-nationally - Values, the theory of planned behavior, and value-belief-norm theory. Environment and Behavior, 38(4), 462-483. https://doi.org/10.1177/0013916505286012

Papagiannakis, G., \& Lioukas, S. (2012). Values, attitudes and perceptions of managers as predictors of corporate environmental responsiveness. Journal of Environmental Management, 100, 41-51. https://doi.org/10.1016/j.jenvman.2012.01.023

Pastor, J. C., \& Mayo, M. (2008). Transformational leadership among Spanish Upper Echelons: the role of managerial values and goal orientation. Leadership \& Organization Development Journal, 29(4), 340-358. https://doi.org/10.1108/01437730810876140

Potočan, V., \& Mulej, M. (2007). Transition into innovative enterprise. Maribor, Slovenia: Faculty of Economics and Business.

Potocan, V., Mulej, M., \& Nedelko, Z. (2013). The influence of employees' ethical behavior on enterprises' social responsibility. Systemic Practice and Action Research, 26(6), 497-511. https://doi.org/10.1007/s11213-013-9299-3

Potocan, V., \& Nedelko, Z. (2015). A new socio-economic order: Evidence about employees' values' influence on corporate social responsibility. Systems Research and Behavioral Science, 32(2), 230-239. https://doi.org/10.1002/sres.2264

Potocan, V., Nedelko, Z., Peleckienè, V., \& Peleckis, K. (2016). Values, environmental concern and economic concern as predictors of enterprise environmental responsiveness. Journal of Business Economics and Management, 17(5), 685-700.

https://doi.org/10.3846/16111699.2016.1202315

Price, J. M., \& Sun, W. (2017). Doing good and doing bad: The impact of corporate social responsibility and irresponsibility on firm performance. Journal of Business Research, 80, 82-97. https://doi.org/10.1016/j.jbusres.2017.07.007

Ralston, D. A., Egri, C. P., Reynaud, E., Srinivasan, N., Furrer, O., Brock, D., \& Wallace, A. (2011). A twenty-first century assessment of values across the global workforce. Journal of Business Ethics, 104(1), 1-31. https://doi.org/10.1007/s10551-011-0835-8

Schermerhorn, J. R. (2008). Management. New Jersey, NJ: John Wiley \& Sons.
Schultz, P. W. (2001). The structure of environmental concern: Concern for self, other people, and the biosphere. Journal of Environmental Psychology, 21(4), 327-339. https://doi.org/10.1006/jevp.2001.0227

Schultz, P. W., \& Zelezny, L. (1999). Values as predictors of environmental attitudes: Evidence for consistency across 14 countries. Journal of Environmental Psychology, 19(3), 255-265. https://doi.org/10.1006/jevp.1999.0129

Schumpeter, J. A. (1992). Capitalism, socialism, and democracy. London: Routledge.

Schwartz, N. (1999). Self-reports: How the questions shape the answers. American Psychologist, 54(2), 93-105. https://doi.org/10.1037/0003-066X.54.2.93

Schwartz, S. H. (1992). Universals in the content and structure of values - Theoretical advances and empirical tests in 20 countries. Advances in Experimental Social Psychology, 25, 1-65. https://doi.org/10.1016/S0065-2601(08)60281-6

Schwartz, S. H., Cieciuch, J., Vecchione, M., Davidov, E., Fischer, R., Beierlein, C., \& Konty, M. (2012). Refining the theory of basic individual values. Journal of Personality and Social Psychology, 103(4), 663-688. https://doi.org/10.1037/a0029393

Skarzynski, P., \& Gibson, R. (2008). Innovation to the Core. Boston, MA: Harvard Business Press.

Stern, P. C. (2000). Toward a coherent theory of environmentally significant behavior. Journal of Social Issues, 56(3), 407-424. https://doi.org/10.1111/0022-4537.00175

Valackiene, A., \& Miceviciene, D. (2015). Promoting socially responsible business at enterprise level: Theoretical approach. Journal of Business Economics and Management, 16(3), 558-570. https://doi.org/10.3846/16111699.2012.745814

Vitell, S. J., \& Hidalgo, E. R. (2006). The impact of corporate ethical values and enforcement of ethical codes on the perceived importance of ethics in business: A comparison of us and Spanish managers. Journal of Business Ethics, 64(1), 31-43. https://doi.org/10.1007/s10551-005-4664-5

Wang, H., Tong, L, Takeuchi, R, \& George, G. (2016). Corporate social responsibility: An overview and new research directions. Thematic issue on corporate social responsibility. Academy of Management Journal, 59(2), 534-544. https://doi.org/10.5465/amj.2016.5001

Wynder, M., \& Dunbar, K. (2016). Ethical values in the evaluation of corporate social performance. Managerial Auditing Journal, 31(2), 180-196. https://doi.org/10.1108/MAJ-09-2014-1092 